\title{
THE SEVENTH SESSION OF THE WHO REGIONAL COMMITTEE FOR SOUTH EAST ASIA
}

The Seventh Session of the WHO Regional Committee for South-East Asia was held in New Delhi from 2Ist to 25th September, I954. At this session leprosy featured prominently in both the Sixth Annual Report of the Regional Director and the Regional Programme and Budget Estimates for 1956, as also in the discussion on these two documents.

In his report the Regional Director referred to the recommendation of the Regional Committee at its Sixth Session in 1953 regarding the need for augmenting efforts in the field of leprosy. He stated that almost all countries in the Region have been giving increasing attention to this problem, and outlined anti-leprosy activities in the various countries with WHO aid.

In Burma the Leprosy Control Project was started in August, I952, following the report of the WHO Leprosy Consultant, who made a survey in I95I. The IVHO Leprosy specialist provided to the Government of Burma in 1952 terminated his activities towards the end of 1953 and the project is being further developed by the national staff. Outstanding developments are the: (I) establishment of a Central Leprosy Institute in Rangoon to direct and guide the national campaign as well as conduct research and training activities, (2) opening of a new State Sanatorium for the care of patients, (3) introduction of methods for early detection and treatment, and (4) utilisation of auxiliary personnel in the expanded programme.

In Ceylon, the Leprosy Control Project was based on the report of the WHO specialist who made a survey in $195 \mathrm{I}$. A leprologist is in the country since June 1954 and an occupational therapist will be recruited shortly.

In India, a national control campaign has been instituted, and plans have been made for the early organisation of modern anti-leprosy units in the different States in endemic areas and gradual increase of such units throughout the country. This plan is also under discussion for UNICEF and WHO assistance.

In Indonesia, plans for an intensive anti-leprosy programme, with the possible assistance of UNICEF supplies and equipment, are being made. WHO has been requested to provide the services of a leprosy consultant for a period of 3 months in I 954 to carry out a survey and it is proposed to provide this. Subsequent assistance will depend on his findings.

In Thailand, a leprosy survey has been conducted in 1953 by a WHO leprologist and his report has been submitted to the government. At a conservative estimate the total number of cases of leprosy in Thailand is at least 100,000. The existing anti-leprosy services are inadequate to meet the need for adequate case finding, treatment, and follow-up. Following are some of the recommendations made by the consultant: ( I) The antileprosy work in Thailand be done on a regional basis. (2) There be a colony and hospital in each region under the charge of a trained medical graduate, who may also act as Regional Leprosy Officer. (3) A strong anti-leprosy unit be set up at the centre in the Public Health Department 
to co-ordinate leprosy work throughout the country and to arrange for the training of all the necessary personnel of various categories. (4) Intensive sulphone treatment of all cases through leprosy clinics or dispensaries, with selective and discriminate isolation of highly infectious cases in leprosy colonies or settlements of simple and cheap type, and the health education of the public in general. The Government of Thailand are considering these recommendation and, to help carry them out, they have requested the services of a WHO leprosy expert.

During a discussion of the Regional Director's Report, the delegates from India, Ceylon, Indonesia and Thailand commented on the leprosy control situation in their countries. The delegates from Ceylon raised the question of a possible conference or study group on leprosy in view of some difference of opinion in his country on modern methods of leprosy control. The Regional Director suggested that he would welcome proposals for a group of leprosy workers from Ceylon to visit countries where modern leprosy control methods were in operation, or to send consultants from outside Ceylon or arrange for holding of a seminar. After some discussion, it was agreed that it was not yet opportune to hold a conference but to await a concrete request from Ceylon Government.

The Regional Programme and Budget Estimates for I956, together with revised programme of work for 1955, were approved with some minor changes made by the Programme Sub-Committee. In introducing the proposed programme and budget estimates, the Regional Director remarked that these had been developed in such a way as to greatly reduce the possibility of dislocation on Regular Budget of any fluctation in the funds from Technical Assistance and other extra budgetary sources. He pointed out that the proposed programme reflected the increasing integration of WHO assistance in national long-term programmes, Leprosy Control Programme being amongst such long-term projects. The proposals and budget estimates for leprosy for I955 and I956 in the various countries of the region are as under: In Burma, where the leprosy control project has now been taken up by the Government, there is a provision for $\$ 1,300$ under regular budget during 1955, and none during 1956. In Ceylon, where the leprosy project was commenced in I954, it is proposed to continue it during I955 and I956; the provision under regular budget for the two years is $\$ 16,320$ and $\$ 10,220$ respectively. In Indonesia under the regular budget there is a provision for a leprologist during I955 and 1956, with equipment and supplies, possibly from other extra-budgetary funds. The regular budget estimate for the two years is $\$ 10,830$ and $\$ I I, 400$ respectively: under other extra-budgetary funds there is a provision for $\$ 25,000$ and $\$ 20,000$ for the two years respectively. 
For Thailand there is provision for a leprologist during I955 and 1956, and it is hoped to secure equipment and supplies through other extra-budgetary funds. Under the regular budget there is provision for $\$ 12,200$ and $\$ 10,820$ for the two years respectively: under the extra-budgetary funds the provision is for $\$ 30,000$ and $\$ 25,000$ respectively.

There is reported in Hindu, a Madras journal, a statement made at the opening of a leprosy clinic in the Cuddalore District of Madras State, that " in. that district there were 2,315 villages with a population of 27 lakhs $[2,700,000]$, of which 150,000 were affected." This, if correct, means that about $5 \frac{1}{2}$ per cent of the population are suffering from leprosy. It is proposed to have one treatment centre for every ten villages, the expense to be met largely by public donations. 